\title{
THE 'COSTANZO OBLIGATION' OF NATIONAL ADMINISTRATIVE AUTHORITIES IN THE LIGHT OF THE PRINCIPLE OF LEGALITY: PRODIGY OR PROBLEM CHILD?
}

\begin{abstract}
Maartje Verhoeven*
Summary: If there is a conflict between a provision of national law and a directly effective provision of EC law, administrative authorities are obliged to set aside national law if consistent interpretation of the latter is not possible, and eventually to apply directly effective provisions of Community law instead. This obligation, which the European Court of Justice (ECJ) has clearly formulated for both primary EC law and secondary legislation, is hereinafter for reasons of convenience referred to as the 'Costanzo obligation'. Although this obligation may seem entirely clear cut and explicable from a European perspective, problems may occur from the point of view of national constitutional and administrative law. In this paper, the effect of the 'Costanzo obligation' with regard to the principle of legality in Germany, France and the Netherlands is discussed.
\end{abstract}

\section{Introduction}

A great amount of the European Court of Justice case law is devoted to the obligations and powers of national courts. ${ }^{1}$ National administrative authorities, however, have also been given their own independent obligations under EC law. These obligations are rather under-researched, but their importance cannot be underestimated, as the application of Community law primarily takes place in administrative decisions, of which only a very low number ends up in court proceedings. Hence, the effectiveness of Community law in practice largely depends on its application by administrative authorities.

The Court of Justice has established an important obligation for national administrative authorities for cases in which a conflict arises between provisions of national law and provisions of EC law. In brief, if there is a conflict between a provision of national law and a directly effective provision of EC law, all administrative authorities are obliged to set

\footnotetext{
* Europa Institute, Utrecht University. The author would like to thank Prof Sacha Prechal and Prof Rob Widdershoven for their valuable comments.

1 See very extensively on this topic M Claes, The National Courts' Mandate in the European Constitution (Hart Publishing, Oxford and Portland, Oregon 2006).
} 
aside the provision of national law if consistent interpretation of the latter is not possible, and eventually to apply the directly effective provisions of Community law instead. ${ }^{2}$ Hence, when a provision of national law is, for instance, incompatible with the freedom of establishment, national administrative authorities are no longer allowed to apply the national provision concerned. This obligation to disapply national law, which the European Court of Justice (ECJ) has clearly formulated for both primary EC law $^{3}$ and secondary legislation, ${ }^{4}$ is hereinafter for reasons of convenience referred to as the 'Costanzo obligation'. The obligation may seem entirely clear cut and explicable from a European perspective, as it follows from the principle of primacy of Community law. In other words, it guarantees the effective and uniform application of Community law by obliging administrative authorities in very general terms to set aside all conflicting rules of national law. Nevertheless, problems may occur from the point of view of national constitutional and administrative law.

In this article, the effect of the 'Costanzo obligation' with regard to the principle of legality is discussed. In subsection 2, the development of the 'Costanzo obligation' in Luxembourg case law is discussed. Then, the focus is shifted to the tension this obligation causes with regard to the principle of legality in the national legal orders of the Member States. Since it is hardly possible to discuss this topic in general terms for all Member States, this article focuses on France, Germany and the Netherlands as examples. Subsection 3 briefly discusses the contents of the principle of legality in these three Member States. Two main dimensions can be distinguished within this principle: the precedence of statutory law and the requirement of a statutory basis. These elements are discussed respectively in subsections 4 and 5, both also including the consequences of the 'Costanzo obligation'. Finally, subsection 6 provides some concluding observations.

In general, it should be stated that the aim here is to pay equal attention to the situation in the three Member States concerned, although this may sometimes not be possible when a topic is far more fiercely debated in one of the countries. Moreover, it should be emphasised that the problems encountered in the three chosen legal systems are not always comparable. As different legal systems organise power differently, the relationship between different branches of government differs. Therefore,

\footnotetext{
2 See for example Case 103/88 Costanzo [1989] ECR 1839; Case C-224/97 Ciola [1999] ECR I-2517 and Case C-198/01 Consorzio Industrie Fiammiferi (CIF) [2003] ECR I-8055.

3 Case C-198/01, Consorzio Industrie Fiammiferi (CIF) [2003] ECR I-8055.

4 For the instrument of the regulation, this obligation can be derived from its nature and character as laid down in art $249 \mathrm{EC}$; for the directly effective provisions of directives that have not been correctly implemented in good time, this was decided in the Fratelli Costanzo case.
} 
both the problems that national administrations encounter, and likewise, the solutions to those problems under domestic constitutional law, will differ. Often the German doctrine is discussed a little more extensively, since it pays considerable attention not only to the principle of legality, but also to the 'Costanzo obligation'.

\section{The 'Costanzo obligation' in the case law of the Court of Justice}

Administrative authorities can come across incompatibilities between the provisions of national law and the provisions of EC law in different situations. In this regard, the literature often distinguishes indirect collisions and direct collisions. ${ }^{5}$

Indirect collisions concern cases in which EC law provides substantive rules on the case concerned, whereas the application of these rules depends on national procedural law, which may limit the effects of the substantive provisions of EC law. In such cases, the provisions of national law at stake are examined in the light of the principles of equivalence and effectiveness, which have been developed in the case law of the ECJ, and which provide respectively that the rules that are applied on actions in which EC law is involved cannot be less favourable than those relating to similar actions not involving an EC law component, and that national procedural rules may not render the exercise of rights conferred by Community law virtually impossible or excessively difficult. When the assessment of national law in the light of these principles does not lead to a solution, for instance because the powers of the national administrative authority under national procedural law are very limited or even absent, the so-called 'procedural rule of reason' test applies. This test assesses whether the reduction of the effectiveness of EC law can be justified by the principles which underlie national procedural law. This does not automatically lead to the setting aside of the national procedural law, as for example the Kühne \& Heitz case shows: only under specific circumstances are administrative authorities obliged to review administrative decisions which are contrary to EC law. ${ }^{6}$

A direct collision exists when a provision of national law conflicts with a provision of EC law, and when the two cannot be applied simultaneously because that would lead to incompatible legal consequences. This is often the case when both provisions have a substantive character. In such cases, administrative authorities have different options to resolve the conflict. All options follow from the principles of direct effect, primacy

\footnotetext{
5 M Niedobitek, 'Kollisionen zwischen EG-Recht und nationalem Recht' (2001) Verwaltungsarchiv 58.

${ }^{6}$ Case C-453-00 Kühne \& Heitz [2004] ECR I-837.
} 
and consistent interpretation. The precise function and role of each of these principles can be explained in the light of the 'three step model' as developed by Prechal. ${ }^{7}$ Although this model was primarily developed for national courts, it can be applied on national administrative authorities as well.

The first step is that administrative authorities are primarily obliged to apply EC law. This obligation is inherent in the principle of direct effect, which implies in the first place that administrative authorities have to assess whether a conflict exists between such a norm and the provisions of national law. Hence, the provision of EC law functions as a standard of review for national law.

If a conflict exists, two options are available as a second step. In the first place, the conflict can be solved by the consistent interpretation of the national law provisions concerned. This 'obligation to interpret' is based on the loyalty obligation of Article $10 \mathrm{EC}$ and is even regarded as 'inherent in the system of the Treaty'. ${ }^{8}$ The obligation as such is limited by the principle of legal certainty and cannot for example lead to contra legem interpretation. ${ }^{9}$ Consistent interpretation may be an attractive option, since an outright choice for one of the conflicting rules can then be avoided. Nevertheless, it may also have big consequences, and might come in practice pretty close to the rewriting of domestic law. Compare for example the ATM case of the Dutch Council of State, ${ }^{10}$ in which a Dutch statute only allowed the prohibition of the export of waste if it jeopardised the implementation of plans and programmes prepared by the Dutch environment minister for the disposal of hazardous waste. Directive 84/361, however, only permitted an export ban if this 'would adversely affect the implementation of a plan prepared pursuant to Article 12 of Directive 78/319 or Article 6 of Directive 76/403'. The Council then compared the two provisions and concluded that that Dutch legislation was drafted too broadly. Therefore, it interpreted the domestic legislation in the light of the Directive provision, thus de facto redrafting it.

The other option to solve the conflict, particularly when consistent interpretation cannot resolve the apparent incompatibility, is the disapplication of the conflicting provisions of national law. This obligation follows from the principle of the primacy of EC law. It follows from cases

\footnotetext{
7 S Prechal, 'Direct Effect, Indirect Effect, Supremacy and the Evolving Constitution of the European Union' in C Barnard (ed) The Fundamentals of EU Law Revisited: Assessing the Impact of the Constitutional Debate (Oxford University Press, Oxford 2007).

8 Joined cases C-397/01 to C-403/01 Pfeiffer [2004] ECR I-8835.

9 Compare for instance Case 80/86 Kolpinghuis ECR 3969, Case C-105/03 Pupino [2005] ECR I-5285 and Case C-168/95 Arcaro [1996] ECR I-4705.

10 Dutch Council of State 15 December 1994 AB 199629.
} 
such as Fratelli Costanzo, ${ }^{11} \mathrm{CIF}^{12}$ and Ciola $^{13}$ that administrative authorities are obliged to do so if consistent interpretation does not lead to a solution. This does not necessarily mean that the provision concerned is rendered invalid or null and void - in the sense of the German term Geltungsvorrang - since it may be lawfully applied in other cases. Its application is only excluded in the case concerned. However, this obligation is unequivocal and uncompromising: ${ }^{14}$ all national legislation has to be reviewed in the light of EC law, regardless of the nature of the national rule in question. Moreover, the obligation applies to all administrative authorities, from ministers to decentralised bodies.

When disapplication of a provision of national law is required, one has to bear in mind that the principle of primacy is a negative rule of instruction: it only implies that certain rules of national law cannot be applied in a specific case. In some cases, solely setting aside national law may be enough to solve the conflict, for example when EC law is relied upon by means of an exception of illegality in administrative proceedings, or when national criminal law provisions which define a criminal offence are inapplicable, or, for instance, when the disapplication may imply that a 'default provision' becomes applicable. In such cases, the sole disapplication of national law suffices to solve the case. This way of precluding the application of national provisions which are incompatible with EC law is the so-called 'exclusionary effect'.

In some cases, however, the disapplication of the provisions of national law does not bring the case to a satisfactory end. In such cases, a third step is required, for which two options are available. Firstly, provisions of EC law may be applied instead of the national provisions by way of substitution. This may occur, for instance, if a claim is directly based on EC law, or if a legal gap is caused by the setting aside. Alternatively, the remaining national law - which could still be applied despite the fact that other incompatible provisions have been set aside - may be interpreted in the light of EC law. If no options are available, state liability may be the final option.

\section{The legality principle in the national legal order}

The principle of legality exists in all Member States of the European Union, although the precise contents and scope may differ from country

\footnotetext{
11 Case 103/88 Costanzo [1989] ECR 1839.

12 Case C-198/01 Consorzio Industrie Fiammiferi (CIF) [2003] ECR I-8055.

13 Case C-224/97 Ciola [1999] ECR I-2517.

14 Compare extensively Claes (n 1) 266-278.
} 
to country. ${ }^{15}$ The background and goal of the principle, however, is comparable in all Member States. The requirement of legality of the administration is one of the main elements of the rule of law which governs the Rechtsstaat or l'État de droit. ${ }^{16}$ The main goal of the principle of legality is to protect individuals against arbitrary interventions in their rights and freedoms by administrative authorities. ${ }^{17}$ Moreover, the principle is closely related to the principle of democracy, since it requires a democratic basis for such interventions. In the words of Schwarze:

regardless of the name it is given or the form it takes, the powers of the state are limited in every country by law, for the purpose of protecting civil liberties. Under the influence of the democratic principle, Acts of Parliament have become the most significant legal constraint on the State's area of influence. ${ }^{18}$

In general terms, one may say that all Member States know a principle which requires that administrative authorities have no powers other than those acquired under general applicable rules. Hence, the legality principle prevents the government from acting arbitrarily and it promotes predictability, stability, legal certainty and equality before the law. ${ }^{19}$

This article will concentrate on the principle of legality as it is perceived in the legal systems of Germany, France and the Netherlands. As stated above, the relationship between the different branches of government differs in these countries. This also has its consequences for the status and contents of the legality principle. In German law, the principle is known as the principle of Gesetzmäßigkeit, and is codified in Article 20 para 3 GG: 'the legislature shall be bound by the constitutional order, the executive and the judiciary by law and justice'. ${ }^{20}$ Hence, executive power must be exercised in accordance with statute and law. Moreover, under Article 1 para 3 GG its exercise is also subject to respect for fundamental rights. In France, le principe de légalité ${ }^{21}$ is not explicitly codi-

\footnotetext{
15 J Schwarze, European Administrative Law (Sweet \& Maxwell, London 2006).

16 JB Auby and L Cluzel-Métayer, 'Administrative Law in France' in RJGH Seerden (ed), Administrative Law of the European Union, its Member States and the United States (Intersentia, Antwerpen-Oxford 2007).

17 L Duguit, Traité de Droit Constitutionnel, Tôme III: La Théorie Générale de l'Etat (Ancienne Librairie Fontemoing, Paris 1930).

18 Schwarze (n 15) 230-231.

19 CAJM Kortmann, Constitutioneel Recht (Kluwer, Deventer 2008).

20 Die Gesetzgebung ist an die verfassungsmäßige Ordnung, die vollziehende Gewalt und die Rechtsprechung sind an Gesetz und Recht gebunden.

21 Some authors prefer the use of the concept of the principe de juridicite over the principe de légalité, because there are more sources of law to which the administration is subordinate than only statutory law; see for example G Dupuis, MJ Guédon and P Chrétien, Droit administratif (Sirey, 2007). Nevertheless, legalité is still most commonly used in French legal writing.
} 
fied in a particular provision of the Constitution, but is applicable as a general principle of law. The same applies to the Netherlands: a general provision which codifies the legaliteitsbeginsel does not exist, but the principle is partly codified in Dutch constitutional law. The Constitution obliges the legislature to regulate in certain areas, such as social security and administrative law (20 (2) and section 107 (2) of the Constitution). Moreover, the Constitution explicitly codifies the legality principle in the field of criminal law (section 15, 16 and 89 (2 and 4)) and tax law (section 104). ${ }^{22}$ For fields that are not explicitly mentioned in the Constitution, the requirement of a basis in statutory law derives from unwritten constitutional law. ${ }^{23}$

The legality principle can be divided into different dimensions in several ways. This article distinguishes two elements: the precedence of statutory law over all secondary sources of law, and the requirement of a statutory basis. ${ }^{24}$ Both elements are present in all three Member States, although the extent of discussion in the literature and case law may differ from state to state. Both the precedence of statutory law and the requirement of a statutory basis are highly relevant for the 'Costanzo obligation' which derives from the case law of the Court of Justice. This obligation leads to two important questions at the national level. Has an administrative authority the power to set aside rules which conflict with higher rules (such as EC law)? And which rules (such as EC law) can serve as a statutory basis for actions by an administrative authority?

\subsection{The precedence of statutory law}

The principle of the precedence of statutory law is present in all three Member States. According to this principle, acts of parliament have priority over 'lower' rules, such as regulatory acts adopted by administrative authorities. In this article, a distinction is made between statutory law (acts of parliament) and 'understatutory' law (such as regulatory acts adopted by administrative authorities such as ministers, but also including regulations of decentralised entities). This distinction is in line with German and Dutch literature, which distinguishes between 'statutes in the formal sense of the word' and 'statutes in the material sense of the word'. The former concerns acts which have been established in the formal process of lawmaking, which involves the participation of parliament. This is as opposed to 'statute in the material sense of the word', which is

\footnotetext{
22 See in more detail KLH van Mens, Legaliteit en belastingrecht (Kluwer, Deventer 1988).

23 See also on this topic, although a little outdated, IC Van der Vlies, Het wetsbegrip en beginselen van behoorlijke regelgeving (Universiteit van Amsterdam, Amsterdam 1984).

24 F Ossenbühl, HStR III nr 62 Rn 13; Schulze-Fielitz in Dreier, GG Kommentar 221.
} 
defined as an act of a competent authority which provides general binding rules. Hence, a statute in the material sense of the word, referred to in this article as 'understatutory' law, has a broader meaning, including not only acts of parliament but also regulations adopted by ministers or decentralised authorities.

The distinction between statutory law and 'understatutory' law fits perfectly well with the German and Dutch situation. The French position, however, is rather different. The French administration has a relatively strong stance in relation to the position of the legislature. Articles 34 and 37 of the French Constitution define the domaine législatif and the domaine réglementaire. Article 34 provides a list of matters on which Parliament is empowered to legislate in lois. Article 37 provides that all matters outside the scope of Article 34 belong exclusively to the pouvoir réglementaire (regulatory power) of the executive. ${ }^{25}$ Hence, the French executive branch has a very strong position, since the power of parliament to adopt lois is listed in an exhaustive account, whereas the executive is empowered to adopt règlements on all other subjects. In this regard, technically the expression 'understatutory law' often does not apply in France, because of the division of areas in Articles 34 and 37 of the French Constitution. Although in the domaine législatif regulatory acts which are based on (and subordinate to) the statute concerned are obviously also adopted, this does not apply to the regulations which are directly based on Article 37 of the French Constitution. Strictly speaking, these are not 'understatutory', but rather 'underconstitutional'. Having made this remark, for reasons of convenience the term 'understatutory' is nevertheless applied in this article.

In Germany, the precedence of statutory law (Vorrang des Gesetzes or Gesetzesvorrang) derives from the fact that both administrative authorities and courts are bound by Gesetz und Recht. ${ }^{26}$ Gesetz incorporates every role of written law, both of a German or of an EC origin. ${ }^{27}$ Hence, both primary and secondary EC law and decisions of the European Court of Justice are accepted as being incorporated in the concept of Gesetz und Recht. ${ }^{28}$ The Gesetzesvorrang binds the national administrative authorities to apply every statutory law. ${ }^{29}$ Every exception to this rule would require an explicit statutory basis. ${ }^{30}$

\footnotetext{
25 CE 8 August 1919 Labonne (Rec 737); CE 7 February 1936 Jamart (Rec 172).

26 H Schulze-Fielitz in Dreier, GG Kommentar Rn 15/16 221.

27 Jarass/Pieroth GG Kommentar 2007 art 20 Rn 38; Sachs SA 107; BverwGE 74, 241, $248 \mathrm{ff}$.

28 On the basis of the treaties of accession in combination with art 23 I GG.

29 F Ossenbühl HStR III nr 62 Rn 4.

30 BVerfGE 25, 216 (228); BVerfGE 30, 292, 332.
} 
Moreover, the German federal legal system has a clear hierarchy. Within the German legal order, three types of law should be distinguished: Bundesrecht, Landesrecht and autonomes Recht. The law of the Bund and of the Länder are considered to be state law, and have precedence over autonomous laws, such as municipal statutes. ${ }^{31}$ The relation between the law of the Bund and the Länder is governed by Article 31 GG: Bundesrecht bricht Landesrecht. Within the legal order of either the Bund or one of the Länder, a fixed hierarchical pattern exists. The highest source of law is the Constitution, followed by statutory law, and 'understatutory' laws (such as rechtsverordnungen).

In the Netherlands, the precedence of statutory law is also regarded as an unwritten rule which derives from the legality principle. Although literature on the legality principle seems to focus on the requirement of a statutory basis (which will be discussed below), the legality principle also provides that powers of administrative authorities have to be exercised within the boundaries prescribed by higher rules of law.

In France, the precedence of statutory law over 'understatutory' law is already embedded in the system of hiérarchie des normes, which is very well developed in both French case law and legal writing. Problems of incompatibility and legality are often approached from the point of view of the hierarchy of norms, and also solved by the application of the hierarchy of norms. Moreover, the precedence of statutory law is also identified as an important feature of the legality principle by most writers. It is clear that it is closely related to the hierarchy. In the words of Chapus:

la légalité est faite d'un ensemble hiérarchié et complexe de norms constitutionnelles, legislatives, jurisprudentielles, réglementaires, auxquelles s'ajoutent diverses norms procédant de conventions internationales. ${ }^{32}$

\section{2. 'The Costanzo obligation' and the precedence of statute law}

The principle of the precedence of statutory law automatically leads to the question of to what extent national law permits administrative authorities to examine whether rules of statutory law are compatible with higher sources of law, such as the Constitution or EC law. With regard to EC law, the ECJ unambiguously obliges administrative authorities to carry out this examination. But does this lead to tensions in the national legal system?

\footnotetext{
31 F Ossenbühl in HU Erichsen, D Ehlers, P Badura et al, Allgemeines Verwaltungsrecht (De Gruyter, Berlin 2006) 189.

32 R Chapus, Droit administratif général - Tome 1 (Montchrestien, Paris 2001).
} 


\section{Germany}

The issue of whether administrative authorities have the competence not to apply statutory provisions that in their view are in conflict with higher ranking law is known in German literature as the question of the Prüfungs- und Verwerfungskompetenz der Verwaltung. ${ }^{33}$ Ensuring Gesetz und Recht implies on the one hand that the administrative authorities are competent to check whether the rules, concerned in a particular case are compatible with higher ranking sources of law (and thus have so-called Prüfungskompetenz). ${ }^{34}$ Nevertheless, the consequences that it can draw from this check are far more controversial. In other words, the so-called Verwerfungskompetenz, which concerns the question of to what extent the administration is also empowered to set aside a statute or another act which it deems contrary to higher ranking law, is far more debated in literature.

The general opinion in German legal writing is that administrative authorities are not entitled to set aside national statutory law which is deemed contrary to the Constitution, although opinions in the literature differ. The only possibility for an administrative authority that is convinced that a provision of statutory law is null and void, or that doubts the validity of a provision, is to obtain an order of the next higher ranking administrative authority. When the higher ranking administrative authority is of the opinion that the rule concerned is valid, this decision is to be followed and hence the norm is to be applied. However, if the higher ranking administrative authority shares the doubts about the validity of the statutory provision, it can ask the government to request an abstract control of norms by the Bundesverfassungsgericht in accordance with Article 93 I GG, or by the Landesverfassungsgericht in the case of inconformity with the Landesverfassung. Of course, the authority concerned can also try to persuade the Bundesregierung or Landesregierung concerned to start such an action. ${ }^{35}$ Nevertheless, in the meantime the administrative authority is obliged to apply the statutory provisions concerned, unless the statute concerned permits the suspension of the administrative procedure if there are severe doubts with regard to the compatibility of this statute with the Constitution. ${ }^{36}$

An exception to the absence of a Verwerfungskompetenz exists: in very rare cases it is accepted that an administrative authority can set

\footnotetext{
33 See for example Ehlers in Erichsen, Ehlers Badura (n 31) 110; H Maurer Allgemeines Verwaltungsrecht (Verlag CH Beck, München 2006) 87 ff; W Erbguth Allgemeines Verwaltungsrecht (Nomos, Baden Baden 2005) 60.

34 Erbguth (n 33) 60.

35 F Ossenbühl HStR III nr 101 Rn 5; Jarass/Pieroth GG art 20 Rn 36.

36 Badura in Badura (n 31) 528.
} 
aside rules which it deems contrary to the constitution. For example, the setting aside of national law is accepted in cases in which the application of the given provision leads to punishable acts, administrative offences or violation of human dignity, because this cannot be required of the public servants concerned. ${ }^{37}$

Although German administrative authorities generally do not have the power to set aside national statutory law, the case law of the Court of Justice obliges them to do so in the case of incompatibility with community law. The obligation of German administrative authorities to apply EC law instead of conflicting national law is widely accepted in German scholarly writing, ${ }^{38}$ although it is rightly seen as an ultima ratio for cases in which consistent interpretation does not help. ${ }^{39}$ Nevertheless, it is also widely accepted in the literature that it leads to several tensions with the principle of precedence of the law.

The topic of the disapplication of national law by administrative authorities is currently frequently discussed in German legal writing due to a recent preliminary question by a German national court with regard to a German administrative authority that disapplied a national law which it deemed contrary to the freedom of establishment. ${ }^{40}$ However, this discussion also existed several decades ago. In 1969 Zuleeg had already accepted the Verwerfungskompetenz of German administrative authorities

37 Ehlers (n 33) 110; compare also the general provisions in art 38 II 2 BRRG 56 II 3 BBG. Compare also Bverw G DVBl 2005 1455, in which it is stated that the obligation of art 11 I SG is limited by the freedom of conscience (art 4 I GG). Besides, in theory, an exception also exists that in cases in which the act concerned is evidently contrary to the Constitution, or when a judicial procedure is pending on the subject, the administration can be relieved of the obligation to apply the law concerned. These exceptions, however, are practically irrelevant in practice.

38 I Pernice in H Dreier, Grundgesetz Kommentar (Siebeck Mohr 2006) 446; R Streinz, 'Der Vollzug des Europäischen Gemeinschaftsrecht durch deutsche Staatsorgane' in J Isensee \& P Kirchhof, Handbuch des Staatsrechts, band VII 1992.

39 C Koenig, 'Bedürfen die Bundesländer einer institutionalisierten Hilfestellung beim Verwaltungsvollzung von Europäischem Gemeinschaftsrecht' (1997) DVBl 581.

40 Joined cases C-171/07 and C-172/07 (Apothekerkammer des Saarlandes) in which a German administrative authority disapplied the German law on pharmacies because it deemed it contrary to the freedom of establishment. Advocate General Bot, however, did not address in his opinion the question whether the authority was obliged to do so even in cases in which the breach of EC law was not very evident. Compare T Diekmann and F Reinhardt, 'Die Filialapotheke der DocMorris NV hat wieder geöffnet' (2007) Wettbewerb in Recht und Praxis 407; W Semmroth, 'DocMorris als Einfalltor für Normverwerfungskompetenz der Verwaltung?' (2006) NVwZ 1378; G Kirchhoff, 'Niederlassungsfreiheit und "Normverwerfungsbefugnis” nationaler Behörden im Fall “DocMorris”' (2007) Zesar 301; R Streinz and C Herrmann, 'Und wieder DocMorris: Das apothenenrechtliche Mehr- und Fremdbesitzverbot aus der Perspektive des Gemeinschaftsrechts' (2006) EuZW 455; C Lafontaine, 'National Law on Pharmacies and its Non-Application by a Member State's Public Authorities - DocMorris again leading the way to accomplish Freedom of Establishment' (2006) ZEuS 301. 
with regard to national law that was incompatible with EC law. ${ }^{41}$ Another example of acceptance of this obligation, even before the Costanzo case, is Scheuing, who argued in 1985 that the reasons why administrative authorities are not entitled to set aside national law which they deem incompatible with the constitution are only applicable to this national situation. He argues that these arguments cannot be applied when EC law is at stake, because neither the Court of Justice nor the BVerfG has a monopoly to set aside conflicting German law (as the BVerfG has with regard to unconstitutional German law), and the Bundesregierung cannot appeal to either of these Courts for judicial review of the national law concerned. ${ }^{42}$

Mögele notes that the 'Costanzo obligation' exceeds the powers that national administrative authorities have to assess the constitutionality of national law, because then they are only in very exceptional cases allowed to set aside national legislation. ${ }^{43} \mathrm{He}$ concludes, however, that EC law should not be judged according to German standards, all the more so because the 'Costanzo obligation' does not - in his view - concern a problem of collisions within one legal order. Therefore, he accepts that the powers of administrative authorities with regard to collisions of national law and EC law are more extensive than with regard to incompatibility with the Constitution. The problems he foresees do not concern the theoretical basis of the obligation, but its application in practice, which requires sufficient knowledge of EC law at the level of the administrative authorities. Mögele introduces several possibilities in this regard, particularly including the possibility to obtain advice in individual cases.

Schmidt-Aßmann distinguishes three different competences within the discussion on the power of administrative authorities to 'set aside' national law: the power to assess whether a provision of national law is in conflict with higher ranking law (Normprüfung), the power to set aside this provision in an individual case (Nichtanwendung einer Norm im Einzelfalle) and the power to declare the provision unlawful and not applicable in general (Normverwerfung in the strict sense). In his view, it is clear that on the one hand every authority is entitled - and obliged - to check whether a norm is in conformity with higher ranking law. On the other, it is also clear that an authority can only have the power to declare a provision unlawful and not applicable in general when it has been explicitly empowered to do so by a statutory provision - which is generally

41 M Zuleeg, Das Recht der Europäischen Gemeinschaften im innerstaatlichen Bereich (Carl Heymanns Verlag, Köln, Berlin, Bonn, München 1969).

42 DH Scheuing, 'Rechtsprobleme bei der Durchsetzung des Gemeinschaftsrechts in der Bundesrepublik Deutschland' (1985) Europarecht 229.

43 R Mögele, 'Deutsches und europäisches Verwaltungsrecht - wechselseitige Einwirkungen’ (1993) BayVBl 552. 
not the case. The in-between power to set aside the conflicting provision in individual cases is controversial, in his opinion.

\section{France}

As said above, French legal writing and case law tend to focus on the disapplication of règlements more than on the setting aside of statutory law. This may be explained by the strong position of the administration in the French legal system, as safeguarded by the Constitution. The position of the administration, however, can obviously only be so strong at the expense of the position of the legislature, as the power to adopt statutes is limited to specific subjects. The obligation to set aside national regulations in the case of conflict with a higher ranking norm has been a general obligation for administrative authorities under French law for a long time. ${ }^{44}$ The background of this general obligation is that it is contrary to public order to allow (let alone oblige) administrative authorities to apply illegal provisions of regulations. ${ }^{45}$ Moreover, the importance of this obligation is strengthened by the fact that an administrative act cannot be annulled by the administrative court with absolute effect when the time limit of the recours pour excès de pouvoir has expired. In such cases, the only option is the invocation of an exception of illegality, which can only lead to the disapplication of the act concerned in the specific case, without erga omnes effect. This increases the importance of the general prohibition to apply illegal acts.

The French hierarchical system thus requires national administrative authorities to set aside regulations which are incompatible with higher ranking sources of law. As will be considered below, this obligation also applies when the higher ranking source of law is EC law. It is, however, important to note that setting aside is not always necessary to safeguard the full effect of EC law. The Conseil d'État has accepted that administrative authorities are obliged to interpret their powers under national law in the light of EC law, for example a directive. ${ }^{46}$ In a more

44 CE 14 November 1958 Ponard Rec 554; CE 9 May 2005 no 277280 Publié au recueil Lebon.

45 Compare the words of Odent, as cited by Fouquet in his note under Alitalia, AJDA 1989 389.

46 CE 8 December 2000 no 204756 Commune de Breil-sur-Roya; see also for example CAA Marseille 16 October 2003, Sarl l'Hermitage Request no 99MA02187 and CAA Paris 10 July 2003, Banque populaire de la region Ouest de Paris Request no 00PA03076, in which lower courts interpret le code général des impôts in the light of the sixth directive. See also CE 21 October 1998 Syndicat national professionnel des médecins du travail no 179771; Europe 1999 no 49, in which the Conseil d'État goes very far in interpreting a national loi in conformity with EC law to avoid having to say that the loi concerned is manifestly incompatible with EC law. 
recent decision in which the EIA Directive was not transposed correctly in time, the Conseil obliged the administrative authority concerned to interpret the existing national provisions in conformity with the goals of the directive. ${ }^{47}$ Consistent interpretation may be a less radical solution to soften incompatibility in practice.

The more severe obligation to set aside provisions of national law which are incompatible with EC law has been the subject of several cases of the Conseil d'État in the last decade. In Danielou, ${ }^{48}$ for example, it ruled that an arrêté interministériel was illegal because it was based on a law which was contrary to a Community regulation. Moreover, in Boisdet the Conseil d'État made it clear that this also applies for statutory law: a provision of a loi which is contrary to EC law cannot be used as a statutory basis for regulation by administrative authorities. ${ }^{49}$

Apart from these more general statements, the obligation for administrative authorities to apply EC law and set aside incompatible national law has been elaborated further by the Conseil d'État in the important cases Vassilikiotis and Association Avenir de la langue française. The general rule that an EC Treaty provision can be applied directly instead of a provision of a national regulation in the case of conflict, can - albeit implicitly - be derived from Vassilikiotis. ${ }^{50}$ In this case, a Greek started an action for excès de pouvoir because an arrêté on diplomas which give right to the issuing of an official museum guide card did not include any foreign diplomas. The Conseil d'État annulled the arrêté because it is contrary to EC law, more precisely to the free movement of workers and to a directive on the mutual recognition of diplomas. Nevertheless, this annulment as such is no solution, because it still does not provide a non-discriminatory rule for foreign workers, and hence creates a legal vacuum.

Because this consequence is undesirable, and since the existing discrimination which is incompatible with EC law has to be solved, the Conseil d'État discussed the consequences of the annulment in more detail. In the first place, the administrative authorities are obliged to adopt, within a reasonable time, rules which are compatible with EC law on the attribution of professional cards. In the meantime, however, they are prohibited to apply the incompatible décret. Hence, the Conseil d'État obliges the administration to deliver a card to EU citizens which apply for it. The authorities should examine these requests case by case in the light of the directive. Although the background of this obligation is clear - to avoid

\footnotetext{
47 CE 6 June 2007 no 292386 Assoc Le Réseau Sortir du Nucléaire; Europe 2007 no 287.

48 CE 11 December 1987 Danielou Rec 409.

4924 September 1990 Boisdet Rec 251.

50 CE 29 June 2001 Vassilikiotis no 213229, Europe 2001 no 265, RFDA 2001980.
} 
several actions whereby several individuals affected by individual decisions seek annulment of the same arrêté - it is remarkable that the Conseil d'État formulates this clear obligation to disapply national law as an interim measure, without a request for interim measures by the party.

The Conseil d'État confirmed the obligation to set aside national law which is incompatible with EC law very explicitly and extensively in 2003 in Association Avenir de la langue française, including the accompanying limits of the obligation. ${ }^{51}$ This case concerned Article 2 of the loi Toubon, which stated that the method of use of a product should be reproduced in the French language. Contrary to this provision, the minister of culture and communication, the state secretary of finance and the state secretary for the economy had issued a circulaire, which stated that this provision was no obstacle to the possible use of other methods, such as pictograms, in combination with a foreign language.

The Association Avenir de la langue française had brought an action against the circulaire, which permitted the use of languages other than French, contrary to the law concerned. The ministers stated that the circulaire aimed to bring the provisions of the loi into conformity with Article $28 \mathrm{EC}$ and the accompanying case law of the ECJ.

Before going into the case at hand, the Conseil d'État considered in very general terms that administrative authorities were obliged to interpret the provisions of national statutory law in the light of EC law. If this were not possible, the minister concerned should instruct its services not to apply the respective national rule.

Afterwards, the Conseil considered that the circulaire was not limited to an interpretation of the loi concerned. The ministers did not instruct their services not to apply Article 2 of the law because of incompatibility with EC law. Instead, they adopted a new rule by means of the circulaire. Because they did not have the power to adopt this circulaire, the attacked provisions of the circulaire had to be annulled because of a lack of competence.

This case clarifies several aspects, as it is drafted in a very clear and general way, providing a vademecum for administrative authorities with regard to the effects of the primacy of EC law..$^{52}$ In the first place, it is clear that administrative authorities are allowed to instruct their services not to apply a law which is incompatible with EC law.

51 CE 30 July 2003 Rec no 245076, AJDA 2003, 2156 case note JM Pontier, Droit Administratif November 2003 no 219 note M Lombard, Europe February 2004 note P Cassia and E Saulnier.

52 D Ritleng, 'Jurisprudence administrative française intéressant le droit communautaire' (2004) Revue Trimestrielle de Droit Européen 338. 
However, in casu, they are not entitled to provide a circulaire with precise positive instructions on what to do, since they lack this competence under national law. In other words, the primacy of EC law does not give the administrative authorities the power to take over the tasks which belong to the legislator in this regard..$^{53}$

\section{The Netherlands}

The power of administrative authorities to set aside provisions which are incompatible with higher sources of law has never been the subject of debate in the Netherlands. This might be explained by the character of the Dutch constitutional system, which is not only monistic in the sense that international law is incorporated in the national legal order, but also in the sense that it is accepted as self-evident that national statutes can be set aside in the case of conflict with international treaties. Some years ago, the interdepartmental commission on European Law (hereinafter referred to as ICER), in which public servants with a legal background of different ministries take part, adopted advice on the application of EC directives by decentralised administrative authorities. In this advice, the question as to whether the administrative authority concerned is competent to set aside provisions of national law which it deems incompatible with EC law is not discussed at all: this competence is assumed on the basis of the case law of the European Court of Justice. ${ }^{54}$ Since both the Council of State and the minister of Justice have endorsed this view, it can be regarded as the general opinion in Dutch constitutional law (all the more so because no constitutional court exists, which increases the importance of such statements for the constitutional doctrine). The advice particularly focuses on the question of how decentralised administrative authorities can comply with this obligation. The ICER has a preference for consistent interpretation of the provision of national law, if possible. Otherwise, when an authority observes an incompatibility between a provision of national law and a provision of an EC directive, it has to assess whether or not the latter has direct effect. To prevent diversity of opinions in this regard, the ICER advises that contact be made with the ministry responsible for implementation, or the Kenniscentrum in this regard. If the directive provision lacks direct effect, it should only be applied if it is directly addressed to the decentralised authority concerned. If the provision is directly effective, the decentralised administrative authorities should apply it if it is beneficial for the private party concerned. If the

\footnotetext{
53 Ritleng (n 52) 338. This limit also applies to the ECHR; see CE 22 October 2003 GISTI et ligue des droit de l'Homme Rec no 248237.

54 Interdepartementale Commissie Europees Recht, advies 'Toepassing EG-richtlijnen door decentrale overheden; ICER-advies en werkgroeprapport' [2003] 2-3.
} 
directive provision has negative implications, the conflicting provision of national law should be applied.

A problem which has attracted special interest in Dutch legal writing and case law is the application of directly effective directive provisions in so-called triangular situations. The European Court of Justice established in the Wells case an obligation for administrative authorities to apply directly effective provisions of directives which are addressed to the Member States in cases in which they are invoked by a third party, even if this causes negative effects for other individuals:

Consequently, an individual may not rely on a directive against a Member State where it is a matter of a State obligation directly linked to the performance of another obligation falling, pursuant to that directive, on a third party. On the other hand, mere adverse repercussions on the rights of third parties, even if the repercussions are certain, do not justify preventing an individual from invoking the provisions of a directive against the Member State concerned. ${ }^{55}$

This rule is accepted and applied by the Dutch administrative authorities and administrative courts; however, it is clear that it can be hard to distinguish when negative effects for third parties are allowed because they are 'mere adverse repercussions'. But what if no third party opposes the granting of certain permission, even though it is clear that certain provisions of a directive have not been correctly transposed? Is the administrative authority then obliged - according to Costanzo - to set aside the conflicting national law and apply the provisions of its own volition? Or is it obliged to apply the - incorrect - national law, because of the prohibition of inverse vertical effects? Under Dutch administrative law, the case law in this respect is rather inconsistent. Whereas the Administrative Law Division of the Dutch Council of State initially held that an administrative authority could only apply a directly effective directive provision against a private party if a third party has invoked that provision, ${ }^{56}$ it changed its case law in 2002, stating that an administrative authority is bound to apply such directive provisions against private parties 'if it were possible that another private party would invoke it before a national court'. ${ }^{57}$ However, the Council has recently decided a case in which it stated that a national administrative authority was not allowed to invoke a provision of the Habitat Directive against a private party, because no

55 Case C-201/02 Wells [2004] ECR I-723; see also recently joined cases C-152/07 and 154/07 Arcor, nyr.

56 ABRvS 29 May 2001, JB 2001/179; ABRvS 23 October 2002, AB 2002417.

57 ABRvS 13 November 2002, AB 200326. 
third party had invoked the provision concerned, ${ }^{58}$ the main reason being that a directive cannot impose obligations on private parties and that it cannot be invoked against a private party. Therefore, the Administrative Law Division deems the ex officio application of a directive in such cases to be contrary to the principle of legal certainty. Obviously, this can lead to rather strange consequences with regard to the application of EC law by national administrative authorities. They are obliged by the Administrative Law Division to take decisions that are clearly in conflict with EC law, and which will be annulled if they are challenged.

\subsection{The requirement of a statutory basis}

The requirement of a statutory basis as a feature of the legality principle is particularly subject to discussion in the Netherlands and Germany. This, obviously, has to do with the fact that both systems know a clear hierarchy of norms in which statutory law, adopted by parliament, has a very strong position. The topic is less discussed in French writing and case law, which tends to focus on the precedence of statutory law. Most French authors assume that it is a self-evident feature of the legality principle that competences of administrative authorities have to have a democratic basis. ${ }^{59}$ Moreover, the lack of discussion in France of the requirement of a statutory basis may be explained by the fact that, as stated above, regulations are more important in the French legal system than statutory law. These règlements still meet the requirement of a statutory basis since their adoption is based on Article 37 of the Constitution, but a basis in an ordinary loi is absent. Finally, the position of the executive branch is strengthened by so-called 'hybrid norms'. These norms - although adopted by administrative authorities - can acquire the status of statute when specific requirements are met. ${ }^{60}$

\subsection{Field of application of the requirement of a statutory basis: Intervening administration versus service administration}

The legality principle in its original form requires that every power of government is based on a statutory rule. As has already been observed, in French doctrine this criterion is not so much subject to debate, but in Dutch legal writing, and particularly in the German doctrine, it is fiercely discussed.

\footnotetext{
58 ABRvS 7 December 2005, AB 200667 (Boxtel); see also ABRvS 1 February 2006 LJN AV0959, from which it can be concluded that Boxtel is settled case law.

59 Chapus (n 32).

60 Dupuis, Guédon and Chrétien (n 21) therefore include this topic in the chapter on laws, as 'texte assimilé à la loi'.
} 
In both the Netherlands and Germany, the requirement of a statutory basis has developed in a more restrictive way, only requiring a statutory basis for obligations and intervening decisions. This also includes, for example, binding prescriptions and de facto obligations. ${ }^{61}$ An example of a binding prescription is a letter by the Chief Inspector of Health to all doctors in the Netherlands prohibiting them from prescribing to drug addicts medicines that fall within the scope of the Opium Act. The power to send such a binding prescription requires a statutory basis, according to the Dutch High Court (Hoge Raad). ${ }^{62}$ The same applies to de facto obligations. A well-known example in this respect is the Dutch Fluoridation case, in which the municipal waterworks of Amsterdam had added fluoride to drinking water to prevent dental decay. When a group of inhabitants opposed this de facto obligation to consume fluoride, the High Court decided that this was unlawful, because a statutory basis was lacking. ${ }^{63}$

A statutory basis is in particular required in both legal systems for unilateral interventions by the government in the rights and freedoms of citizens, ${ }^{64}$ so-called Eingriffsverwaltung or 'intervening administration'. It is unchallenged and undisputed in the literature that such actions require a statutory foundation. ${ }^{65}$ The opposite of Eingriffsverwaltung is non-interfering actions by the government, so-called Leistungsverwaltung or 'service administration', which often concern benefits for the private party concerned, such as the granting of subsidies or other forms of (financial) aid. In both the German and the Dutch legal literature it is still under discussion whether the legality principle requires a legal basis for this kind of action. The general opinion in Germany tends to accept as a compromise that in such cases no basis in statutory law is required, but that a basis in delegated legislation is sufficient.

In the Dutch legal literature, some argue, along the lines of the case law of Hoge Raad, that only the obligations that the government imposes on citizens require a basis in statutory law, and that so-called Leistungsverwaltung does not need a specific legal basis. In this respect, the so-

\footnotetext{
${ }_{61}$ See more extensively F Van Ommeren, De verplichting verankerd (dissertation, VU 1999) 62-106.

62 HR 27 June 1986 NJ 1987898 (Methadonbrief).

63 HR 22 June 1973 NJ 1973386.

64 Schwarze (n 15) 212-232.

65 See for references D Jesch, Gesetz und Verwaltung (Tübingen 1961); WJM Voermans, Toedeling van bevoegdheid (Oratie Leiden, Boom Juridische Uitgevers, The Hague 2004) 3; F J van Ommeren, 'Het legaliteitsbeginsel in het staats- en bestuursrecht: opkomst en ondergang van geïmpliceerde bevoegdheden?' (2002) Rechtsgeleerd Magazijn Themis 124; LJA Damen and others, Bestuursrecht, deel 1: Systeem, Bevoegdheid, Besluitvorming, Handhaving (Boom juridische uitgevers, The Hague 2005) 52.
} 
called 'consistency principle' has been introduced in the literature. ${ }^{66}$ This principle is based on the notion that the main goal of legality is that the actions of the government are foreseeable and thus predictable. The scope of this consistency principle seems to be much wider than the principle of legality: it applies to all actions, because the government should be consistent in all of its actions. Therefore, it is not necessary to qualify the actions of the government as interfering or carrying out administration. This is an advantage, since a distinction between both forms of administration is often difficult to make. For example, the granting of a subsidy often also includes certain conditions that qualify as interference in the rights and freedoms of the party concerned.

\subsection{EC law as a statutory basis? It should be clear who is competent...}

The obligation of national administrative authorities to apply EC law and to set aside incompatible national law in the case of conflict clearly leads to an important question with respect to the formal aspects of the legality principle: are national authorities entitled to do so under national administrative law? Can EC law directly confer powers upon them? As many as 40 years ago Zuleeg accepted that EC law in principle can suffice as a statutory basis. ${ }^{67}$ Due to the development of EC law, and especially the case law of the Court of Justice, such a general answer might need to be put into the current perspective. ${ }^{68}$

In the Dutch discussion, the answer to these questions depends on whether one adopts a strictly national legality principle (by which powers must be based on national legislation) ${ }^{69}$ or whether one argues that a basis in EC law also meets the requirements of a written statutory basis. ${ }^{70}$ In this respect, a distinction should be made between the different instruments of EC law, particularly primary EC law, regulations and directives. This distinction will be discussed in more detail below. However, what can already be said in general is that although some instruments of EC law may theoretically be aptly compared to a statutory basis, the problem is that they are often not very clear as to which administrative

\footnotetext{
66 Van Ommeren (n 61).

67 Zuleeg (n 41) 213.

68 H Rieckhoff, Der Vorbehalt des Gesetzes im Europarecht (Mohr Siebeck, Tübingen 2007). Compare also joined Cases C-383/06 to C-385/06 Vereniging Nationaal Overlegorgaan Sociale Werkvoorziening, nyr.

69 For example, DE Comijs, Europese structuurfondsen: uitvoering en handhaving in Nederland (Kluwer, Deventer 1998).

70 See on this discussion more extensively JH Jans, R de Lange, S Prechal, RJGM Widdershoven, Europeanisation of Public Law, (Europa Law Publishing, Groningen 2007) 23.
} 
authority is competent. This is in line with the principle of national institutional autonomy, which implies that EC law as a rule is only concerned with the Member State as an entity. Therefore, the attribution of powers to national administrative authorities by name is very rarely found in EC legislation. On the contrary, it is generally up to the Member States to decide which administrative authority is empowered to apply and enforce a particular regulation or directive; the given EC legislation only refers to 'the competent authorities'. The Member State is obliged to do this, regardless of whether the regulation or directive contains an explicit obligation to do so. ${ }^{71}$ A complicated situation emerges when this is not done correctly and in due time by the Member State: are the administrative authorities then empowered to apply EC law?

A part of Dutch scholarly writing seems to argue that the legality principle always requires an institutional basis in national law. ${ }^{72}$ Therefore, the lack of a national law that transposes a directive or makes a regulation operational in the sense that a national administrative authority is assigned by name to exercise a certain power basically seems to render the application of the power concerned impossible, because the necessary written statutory basis required by the legality principle is lacking. A recent judgment by the Dutch Council of State also seems to support this view. ${ }^{73}$ Due to the lack of a national statute appointing the competent authorities to apply the power to grant subsidies on the basis of a regulation, it was unclear whether the Provincial Council or the Provincial Executive was competent. Therefore, the Council of State explicitly stated that the regulation in this case could not be lawfully applied because of the lack of a national statute in which the competent authorities are appointed. With regard to non-transposed directives, the ECJ cases of Draempaeh $l^{74}$ and Dorsch Consult ${ }^{75}$ can be referred to as support for the view that they cannot be regarded as a sufficient statutory basis.

${ }_{71}$ See for example Case C-365/93 Commission $v$ Greece [1995] ECR I-499 and Case C186/91 Commission v Belgium [1983] ECR I-851.

72 IC Van der Vlies \& RJGM Widdershoven, De betekenissen van de Nederlandse Grondwet binnen de Europese rechtsorde, Preadvies / Vereniging voor de vergelijkende studie van het recht van België en Nederland (Tjeenk Willink, Deventer 1998) 30; E Steyger, Europees recht en het Nederlands bestuursrecht, Preadvies VAR (Samsom Tjeenk Willink, Alphen aan den Rijn 1996) 28.

73 ABRvS 19 April 2006, LJN: AW2275, AB 2006/296.

74 Case C-180/95 Draehmpaehl [1997] ECR I-2195.

75 Case C-54/96 Dorsch Consult [1997] ECR I-4961. 


\section{4. ... and it also depends on the instrument of the EC law concerned}

Apart from the fact that it should be clear who is competent, the answer whether EC law can function as a direct statutory basis for actions by national administrative authorities depends on the instrument of EC law concerned. In this regard, one has to distinguish between the different sources of EC law. Recently, this has been thoroughly investigated with regard to German law by Henning Rieckhoff, who examines both the EC treaty and the different instruments of secondary law in the light of the German legality principle (Gesetzesvorbehalt). ${ }^{76}$

The EC Treaty

The EC Treaty will in practice only rarely be the basis for acts of the administration, whereas it is elaborated in secondary EC law in most cases. Nevertheless, it is generally accepted that directly effective provisions of the EC Treaty can be equated to a statutory basis under national law. For example, it is in principle also accepted in case law that primary EC law can be the basis of a Verwaltungsakt, as seen in the case where the Bundeskartellamt required German airway companies to disclose their tariffs. ${ }^{77}$

\section{The regulation}

The instrument of the regulation does not seem to cause any particular problems with regard to the Gesetzesvorbehalt, since Zuleeg had already accepted in 1969 that it can be equated to statutory law. ${ }^{78}$ Rieckhoff adds that also nowadays it is not so problematic to see a regulation as a statutory basis for administrative action in the sense of the Gesetzesvorbehalt, especially because of its direct applicability on the basis of Article 249 EC. This makes the regulation an instrument which can both oblige and authorise all legal entities in all Member States equally. ${ }^{79}$ The example of the Banana regulation, on the basis of which the Bundesrat für Ernährung und Forstrwirtschaft prohibited the import of bananas that lacked the required certificates, shows that the regulation functions in practice as a statutory basis for administrative actions as well. This is also clear from Dutch case law, in which the College van Beroep voor het Bedrijfsleven (one of the supreme administrative courts) accepted the

\footnotetext{
76 Rieckhoff (n 68).

77 See Rieckhoff (n 68) 199 for further references.

78 Zuleeg (n 41) 213.

79 Rieckhoff (n 68) 200.
} 
regulation as a statutory basis for actions by administrative authorities. ${ }^{80}$ One has to bear in mind, however, that it has to be clear which administrative authority is competent to apply the regulation. This may cause problems in practice (see above para 5.3).

\section{The directive}

With regard to directly effective provisions of directives, which have not been transposed into national law correctly, the situation is more complicated, due to the fact that directives are addressed to the Member States. With regard to actions of the administration with a positive effect for private parties, no problem exists, because private parties can rely on directly effective provisions towards the state. Rieckhoff, however, rightly states that it is obvious that directives cannot impose obligations on citizens. His arguments for this conclusion are twofold. Firstly, the characteristics of the directive as described in Article 249 EC imply that contrary to the regulation, directives are not directly applicable, but addressed to the Member States. Secondly, Rieckhoff argues that no obligation exists to publish directives, which makes them hardly accessible for private parties. Although this latter argument no longer applies, since the obligation to publish has been introduced in the Maastricht Treaty in Article $254 \mathrm{EC}$ as a general requirement for the coming into force of directives, ${ }^{81}$ the first argument makes sense. When a directive can be applied within the scope of the power of an administrative authority which already exists under national law, no problems exist, provided the prohibition of inverse direct effect of directive provisions is respected. When, however, no power exists, the national administrative authority cannot derive power directly from a directive provision, because of the prohibition of inverse direct effect. ${ }^{82}$ This problem for example occurred when the nitrate directive was not implemented in time in the Netherlands, ${ }^{83}$ and no administrative power existed in which it could be fitted in.

\footnotetext{
80 See CBB 18 February 2009 LJN: BH4548; CBB 18 February 2009 LJN: BH4551; CBB 18 February 2009 LJN: BH4554; CBB 25 February 2009 LJN: BH4690; CBB 25 February 2009 LJN: BH4694; CBB 25 February 2009 LJN: BH4697.

81 Only directives that are not addressed to all Member States and have not been adopted under the procedure of art $251 \mathrm{EC}$ are excluded from this obligation. See also C Trüe, Auswirkungen der Bundesstaatlichkeit Deutschlands auf die Umsetzung von EG-Richtlinien und ihren Vollzug (1996) EuR 183, who argues that this introduction is sufficient answer to this often used argument against the direct effect of directive provisions (as argued by $\mathrm{N}$ Weber, Die Richtlinie im EWG-Vertrag (Gerold und Appel, Hamburg 1974) 108).

82 Case 80/86 Kolpinghuis Nijmegen [1987] ECR 3969.

83 The Netherlands was condemned for this in Case C-322/00 Commission $v$ the Netherlands [2003] ECR I-11267.
} 
The decision

The decision is the third legally binding instrument introduced in Article 249 EC. Although the directive has gained more attention in legal writing thus far, the possibility of direct effect of decisions was already acknowledged by the Court in the Grad case, almost 40 years ago.

The question whether a decision can be equated to a statutory basis depends in my view largely on the character of the decision concerned. It is generally accepted that a distinction can be drawn between on the one hand decisions that affect the legal position of private parties directly (being addressees of the decision concerned), and decisions that do so indirectly on the other hand (in cases in which the decision is addressed to a Member State). It is clear that the former group of decisions can impose obligations upon private parties, even without the intervention of national administrative authorities. With regard to the second group of decisions addressed to the Member States but which do impose obligations on private parties indirectly, Rieckhoff does not make any further distinctions, but merely argues that the view of German scholars differs as to whether this sort of decision can be qualified as a statutory basis for actions by administrative authorities. ${ }^{84}$ In my opinion, this can be brought a bit more into perspective. I think a distinction should be made between, on the one hand, decisions that involve rules of a general nature, which have to be implemented in national law by the addressed Member State, and, on the other hand, decisions that are indirectly, by the intervention of the Member State as addressee, directed at one or more specified parties. The best-known and often used examples of the latter are the decisions that oblige the Member State to reclaim the unlawful state aid of companies that are named in the decision.

The nature of decisions of a general character addressed to Member States seems to be close to the character of a directive. ${ }^{85}$ In the recent CARP case, this has been confirmed: the Court prohibited the horizontal direct effect of a decision, addressed to the Member States, specifying the procedures for attesting the conformity of doors, windows, shutters, blinds, gates and related building hardware which had not been implemented in national law. In my view, this again can be related to the case law on the prohibition of the horizontal direct effect of directives, although until now the Court has never explicitly mentioned this relation. ${ }^{86}$

\footnotetext{
84 Rieckhoff (n 68) 208-209.

85 Compare Case 30/75 Spa Unil [1975] ECR 1419 in which the inverse direct effect of such decisions was denied.

86 M Nettesheim even explicitly says in general that the case law on the direct effect of directives can be applied on the instrument of the decision as well: M Nettesheim in E Grabitz, M Hilf, M Nettesheim (eds), Das Recht der Europäischen Union, (Kommentar, Beck, München 2001) art 249 Rn 203.
} 
It is particularly questionable whether the last group of decisions, addressed to the Member State but nevertheless explicitly involving negative implications for a private party, can function as a statutory basis. This question is answered both positively and negatively in German literature, whereas, interestingly enough, both answers are based on the case law of the Court of Justice.

Some German authors accept state-addressed decisions which include negative effects for explicitly mentioned private parties as a statutory basis. ${ }^{87}$ They mainly do so because such decisions generally do not provide any discretionary space for the authority concerned for implementation in national law. Therefore, in their view, the comparison with directives fails; they see the character of decisions rather closer to the instrument of the regulation.

On the other hand, others argue that the fact that implementation in national law is required is decisive, emphasising that the Member State is the addressee of the decision. ${ }^{88}$ Whereas a decision can only impose obligations on its addressee, as Article 249 EC states, a decision addressed to a Member State cannot directly impose obligations on private parties. This view is, again, based on the idea that the state-addressed decision is closely related to the directive. While a directive cannot directly impose obligations on citizens, the same goes for the state-addressed decision: in such cases, the national act in which state aid is reclaimed is the basis of the negative implications for individuals.

\section{Concluding observations: prodigy or problem child?}

The European Court of Justice has established some clear obligations for national administrative authorities with regard to situations in which provisions of national law are incompatible with EC law. If consistent interpretation in such cases is not possible, the administrative authority concerned is obliged to set aside the incompatible provision of national law, and apply EC law instead if the disapplication leads to a legal vacuum. This obligation can be explained very well from a theoretical

\footnotetext{
87 See for this view, for example, S Kadelbach, Allgemeines Verwaltungsrecht unter europäischen Einfluss (Mohr Siebeck, Tübingen 1998) 231; A Scherzberg, 'Verordnung - Richtlinie - Entscheidung' in H Siedentopf (ed), Europäischen Integration und nationalstaatliche Verwaltung 17 (Steiner, Stuttgart 1997); A Weber, Rechtsfragen der Durchführung des Gemeinschaftsrechts in der Bundesrepublik (Carl Heymanns Verlag, Köln, Berlin, Bonn, München 1987) 19.

88 See for this view, for example, R Greaves 'The Nature and Binding Effect of Decisions under Article 189 EC' (1996) 21 EL Rev 3 (12); Nettesheim (n 86); H Tuengerthal, Zur Umsetzung von EG-richtlinien und staatengerichteten EG-Entscheidungen in deutsches Recht (Peter Lang, Frankfurt 2003) 233; M Vogt, Die Entscheidung als Handlungsform (Mohr Siebeck, Tübingen 2005) $171 \mathrm{ff}$.
} 
point of view, since the principle of primacy requires the setting aside of national law in this regard. Hence, the 'Costanzo obligation' works perfectly well to safeguard the effectiveness of EC law.

Although this obligation is fully acceptable from an EC point of view, the obligation to set aside national law may nevertheless cause important tensions in national constitutional and administrative law. These tensions primarily concern the principle of legality. This principle is well known and is applied in all three investigated Member States, and can be divided into two requirements: the precedence of statutory law, and the requirement of a statutory basis.

The precedence of statutory law provides that statutory law has priority over 'understatutory' law, such as regulations by administrative authorities. This, in combination with the fact that Community law is regarded as a source of law which is higher than statutory law - although subordinate to the Constitution in France and Germany - means that 'understatutory' law has to be in accordance with EC law. Moreover, the 'Costanzo obligation' also establishes that administrative authorities are obliged to set aside statutory law which is incompatible with EC law. This leads to the question about whether administrative authorities are allowed to assess whether statutory law is in accordance with the provisions of EC law, and, if not, whether they are empowered to set aside the incompatible provisions of national law.

This question is answered very differently in the Member States. The three legal systems considered here organise power differently, and thus the relationship between different branches of government differs. Therefore, both the problems that national administrations encounter, and, likewise, the solutions to those problems under domestic constitutional law, differ.

In Germany, the question as to whether administrative authorities are entitled to disapply a statutory norm which they deem contrary to the constitution is a recurring subject of discussion, on which the general opinion seems to be that this power does not exist. With regard to Community law, however, it is accepted in German legal writing that administrative authorities can be obliged to set aside incompatible provisions of statutory law. In France, the instrument of the statute is less important than in Germany and the Netherlands, as rule-making is often done through the adoption of 'understatutory' norms. The setting aside of statutory provisions which conflict with a provision of the EC Treaty, however, has explicitly been accepted by the Conseil d'État. In the Netherlands, the power to set aside rules which are incompatible with higher ranking rules - such as statutory provisions which are incompatible with EC law - has never been a real issue of discussion in the doctrine. This 
power is assumed, for EC law as well as for national sources of law, as deriving from the legality principle and the hierarchy of norms.

The requirement of a statutory basis implies that actions by administrative authorities have to be based on a statutory basis, thus securing the principle of democracy and preventing citizens from suffering arbitrariness. The application of this requirement has been the subject of discussion in the literature, particularly in Germany and - to a lesser extent - in the Netherlands. It is commonly agreed that a statutory basis is anyway required when the action of the administrative authority intervenes in the rights and freedoms of an individual. With regard to service administration, which concerns beneficial decisions with regard to, for example, subsidies and (financial) aid, the applicability of the requirement is more controversial.

After having defined the field of application of the requirement of a statutory basis, it is important to examine whether EC law suffices in this regard. Due to the character of the different instruments, one may generally say that provisions in regulations or in the EC Treaty are more easily accepted as a statutory basis than directive provisions or decisions; in practice, regulations in particular may function as a direct legal basis. However, it has to be clear which administrative authority is competent. If this is not explicitly settled in the regulation - which is often the case as the EC generally respects the principle of national institutional autonomy - the principle of legality requires this to be arranged at the national level, before the regulation can be executed.

To conclude, one may say that the obligations that national administrative authorities have when national law is incompatible with EC law can lead to important questions, which have not yet been answered adequately. Although the basis of the obligation to set aside incompatible provisions of national law is clear and defensible, it is a complicated obligation in practice. In this regard, the lack of some sort of "preliminary procedure', as it exists for national courts, may hinder administrative authorities in their decisions in individual cases about whether a conflict between EC law and national law exists, whether the provision of EC law concerned has direct effect, etc. Hence, administrative authorities have to decide on their own volition whether a national provision should be set aside. Does this imply, as some argue, that the obligation of national administrative authorities to set aside national law which is incompatible with EC law should be restricted to cases where the conflict is clear and obvious, or in which a court - either the ECJ or a national court - has ruled that an incompatibility exists? It is clear that from a theoretical perspective such a limitation would not be welcomed, as it would allow administrative authorities to apply the law wrongfully if no judgment exists on the incompatibility of provisions of national law with EC law. In 
my view, however, this limitation of the 'Costanzo obligation' might be a solution for the practical problems which administrative authorities encounter. Moreover, it also has theoretical advantages, as a limitation of the 'Costanzo obligation' promotes legal certainty, as administrative authorities are only obliged to set aside national law in cases where they are certain that a collision exists and Community law should prevail.

Every coin has its reverse side. The 'Costanzo obligation' is a prodigy from the Community perspective, since it safeguards the effectiveness of Community law, obliging national administrative authorities to grant it priority over incompatible provisions of national law. At the same time, however, from a national law perspective, the obligation may be a problem child for national administrative authorities. 